\title{
Evolution and current scenario of irrigated area in Brazil: Systematic data analysis
}

Daniel F. de Carvalho ${ }^{1}$, Rosária da C. F. Martins², Jaqueline J. S. dos Santos², Gean C. Teles², Marcello A. D. Gentile ${ }^{2} \&$ Marcelo S. de Oliveira ${ }^{3}$

\footnotetext{
${ }^{1}$ Universidade Federal Rural do Rio de Janeiro/Instituto de Tecnologia/Departamento de Engenharia. Seropédica, RJ, Brasil. E-mail: carvalho@ufrrj.br (Corresponding author) - ORCID: 0000-0001-7629-9465

${ }^{2}$ Universidade Federal Rural do Rio de Janeiro/Instituto de Agronomia/Programa de Pós-graduação em Fitotecnia. Seropédica, RJ, Brasil. E-mail: rosaria.cfmartins@gmail.com - ORCID: 0000-0001-7590-2939; jaqueline_jjss@hotmail.com - ORCID: 0000-0001-7824-6893; geancorreteles@hotmail.com ORCID: 0000-0003-0325-3583; gentile.marcello@yahoo.com.br - ORCID: 0000-0002-5471-6499

${ }^{3}$ Instituto Brasileiro de Geografia e Estatística - Diretoria de Pesquisas/Coordenação de Agropecuária/Censo Agropecuário. Rio de Janeiro, RJ, Brasil. E-mail: marcelo.s.oliveira@ibge.gov.br - ORCID: 0000-0002-1630-5314
}

\begin{abstract}
Water is an essential element to life and used in various human activities. However, because of the amount used in agriculture and the increase in irrigated area, the sustainable use of this resource has become a worldwide concern. In this study, data from the Censuses of Agriculture published by the Instituto Brasileiro de Geografia e Estatística (IBGE) from 1960 to 2017 were evaluated in relation to the regions and irrigation methods, performing a detailed analysis between the data from the 2006 and 2017 Censuses. There was an increase in irrigated area in Brazil in all geographic regions, reaching 6.9 million hectares in 2017. Sprinkler irrigation methods are the most used, with $48 \%$ of the irrigated area, followed by localized irrigation (24.4\%) and surface irrigation (22.3\%). Drip irrigation is the most used system in establishments up to 50 ha $(617,423 \mathrm{ha})$, followed by conventional sprinkler $(514,893 \mathrm{ha})$, while the center pivot stands out in areas larger than 50 ha $(1,362,828 \mathrm{ha})$. The Southeast region $(38.6 \%)$ and the states of Rio Grande do Sul (20.4\%), Minas Gerais (16.6\%) and São Paulo (16.0\%) stand out as the ones with the largest irrigated area in the country. The State of Minas Gerais showed the highest growth of irrigated area in the 2006-2017 period (116.1\%), due to the expansion of areas irrigated with center pivot.
\end{abstract}

Key words: census of agriculture, irrigation methods, irrigated area

\section{Evolução e cenário atual da área irrigada no Brasil: Análise sistemática dos dados}

RESUMO: A água é um elemento essencial à vida e empregada em diversas atividades humanas, todavia, em função do montante utilizado na agricultura e do aumento de área irrigada, o uso sustentável deste recurso tem se tornado uma preocupação mundial. Neste estudo foram avaliados os dados dos Censos Agropecuários publicados pelo Instituto Brasileiro de Geografia e Estatística (IBGE) de 1960 a 2017, com relação às regiões e aos métodos de irrigação, sendo realizada uma análise detalhada entre as informações dos Censos de 2006 e 2017. Houve aumento na área irrigada no Brasil em todas as regiões geográficas, atingindo 6,9 milhões de hectares em 2017. Os métodos de irrigação por aspersão são os mais utilizados, com 48\% da área irrigada, seguido pela irrigação localizada $(24,4 \%)$ e superfície $(22,3 \%)$. O gotejamento é o sistema mais empregado em estabelecimentos de até 50 ha (617.423 ha), seguido da aspersão convencional (514.893 ha), enquanto o pivô central é o que se destaca em áreas acima de 50 ha (1.362.828 ha). A região Sudeste $(38,6 \%)$ e os Estados do Rio Grande do Sul (20,4\%), Minas Gerais $(16,6 \%)$ e São Paulo (16,0\%) se destacam como os de maior área irrigada do país. O Estado de Minas Gerais apresentou o maior crescimento de área irrigada no período 2006-2017 (116,1\%), devido à expansão das áreas irrigadas com pivô central.

Palavras-chave: censo agropecuário, métodos de irrigação, área irrigada 


\section{INTRODUCTION}

Water is an essential factor in the maintenance of agricultural and industrial activities (Ding \& Ghosh, 2017) and its optimized use in food production is one of the main challenges, especially in the world scenario of climate change (Saccon, 2018). Although approximately $20 \%$ of the total cultivated area on the planet is irrigated, its participation reaches $40 \%$ of the production of food, fibers and bioenergy crops (FAO, 2017), demonstrating the importance of irrigation for the viability of agriculture, especially in arid and semi-arid regions with high insolation and low precipitation (Winter et al., 2017).

The world's irrigated agriculture occupies an estimated area of $310 \mathrm{Mha}, 75 \%$ of which is located in Asia, where India (66 Mha) and China (62 Mha) are the countries with the largest area equipped for irrigation (FAO, 2017). The irrigated area in Brazil is more than 6.0 million ha (ANA, 2017), ranking it among the ten countries with the largest irrigated area in the world.

Globally, the irrigated area is expected to increase in the next decades and reach 402 Mha by 2030, with 40 Mha in developing countries (Darko et al., 2015). In Brazil, the potentially irrigable area is estimated at $61.4 \mathrm{Mha}$, of which 18.4 Mha is in regions with high suitability of soil and relief (Sparovek et al., 2015). On the other hand, the increase in irrigated area can cause reduction in water reserves and, therefore, the sustainable use of water has increasingly become a global concern (Velasco-Muñoz et al., 2018).

Given the importance of irrigated agriculture in Brazil for food production and the significant increase in this area in the country in recent decades, this study was conducted to evaluate the evolution and current scenario of the irrigated area in Brazil, through a systematic analysis of the available data, taking as reference the Census of Agriculture 2017 (IBGE, 2017).

\section{Material ANd Methods}

This study was conducted using data of the Instituto Brasileiro de Geografia e Estatística (IBGE) available in the Automatic Recovery IBGE System (Sistema IBGE de Recuperação Automática - SIDRA), referring to the Censuses of Agriculture of 1960, 1970, 1975, 1980, 1985, 1995-1996, 2006 and 2017, the last-mentioned preliminarily released in June 2018. For the last Census specifically, the number of agricultural establishments using irrigation and the area of these establishments by irrigation method were evaluated, in addition to the groups of total area and groups of crop area.

Analyses were conducted for: evolution of irrigated area in Brazil by region from 1960 to 2017; comparison of the area by administrative region and of the irrigated area by irrigation system/method between 2006 and 2017; evaluation of the irrigated area by region and by area intended for crops of the agricultural establishment for the irrigation systems drip, micro-sprinkler + other localized systems, flood, furrow, self-propelled sprinkler, center pivot sprinkler, conventional sprinkler, and subsurface + wetting and other methods based on the 2017 Census; and also variation of irrigated area in the ten States with the largest irrigated area in Brazil, comparing the years 2006 and 2017.

For better comparison with previous Censuses, some irrigation methods were grouped into the same classification, with the self-propelled and conventional sprinkler systems classified as sprinkler (without center pivot) and drip and micro-sprinkler systems classified as localized irrigation. The subsurface and wetting irrigation systems and other methods not contemplated in the previous ones formed a specific class, called "other methods".

According to the definition established by the Census of Agriculture, the crop area was considered as the fraction of the total area of the agricultural establishment under permanent or temporary crops on the reference date (30/09/2017) (IBGE, 2017). Thus, it was considered as "producer without crop area" (WCA) the one who, despite owning areas with agricultural exploitation (forestry, pasture, etc.), did not have areas intended for crops on the above-mentioned date, although he/she could have had irrigated areas in the reference period of the Census (01/10/2016 to 30/09/2017). Additionally, in situations in which the area irrigated by a given system referred to less than 3 informants, its value was taken into account, but not discriminated, in order to preserve the identity of the informant/producer. In these cases, the name "X" was used.

\section{RESUlts AND Discussion}

Between 1960 and 2017, the irrigated area in Brazil increased in all geographic regions, reaching 6.99 Mha in 2017 (Figure 1). Compared to the previous Census, there was an increase of $2.36 \mathrm{Mha}$ (51.9\%), and this increase was higher than that observed in the Censuses of Agriculture of 19951996 and 2006, a period in which the irrigated area in Brazil increased from 3.1 to 4.45 Mha (45.6\%) (Paulino et al., 2011).

The Southeast region of Brazil, which until the 1995-1996 Census was the second region of the country with the largest irrigated area, increased its irrigated area by $73.0 \%$ until 2006, surpassing the South region (13\%), still considered a traditional center of irrigated agricultural production (Figure 1).

The increase in irrigated area in the Southeast and South regions continued in the following decade, with 65.8 and

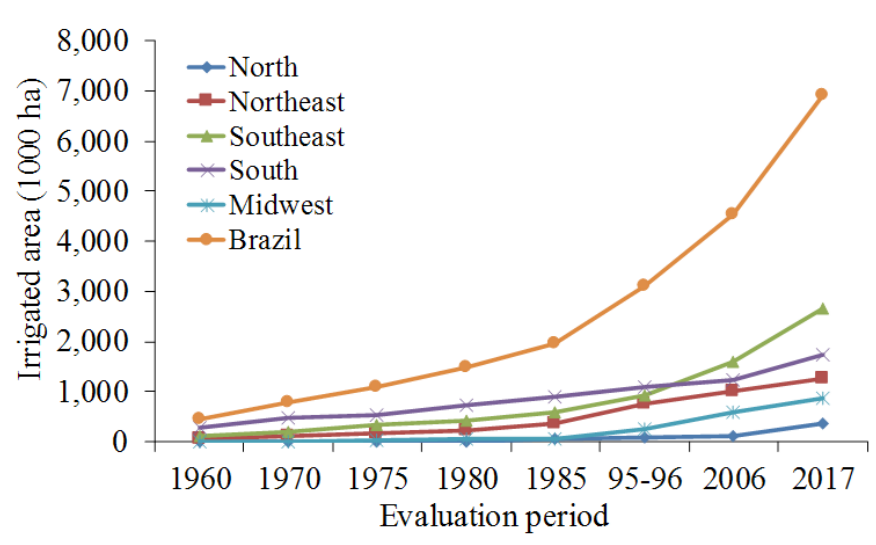

Figure 1. Evolution of irrigated area in Brazil by region from 1960 to 2017 
$39.8 \%$, respectively, and in 2017 , these regions represented 38.6 and $25.1 \%$ of the total irrigated area in the country (Figure 2A). Between 2006 and 2017, the lowest growth of irrigated area was observed in the Northeast region (25.9\%), while the highest growth occurred in the North region (240\%), due to agricultural expansion and investments in public and private irrigated perimeters, especially in the State of Tocantins (Testezlaf, 2017; ANA, 2017).

Despite the expansion observed, the North region still has the smallest irrigated area in the country $(372,185 \mathrm{ha})$ due to its climatic characteristics, with a large area occupied by the Amazon Forest. In the 1995-1996 Census, the irrigated area in this region represented $2.7 \%$ of the irrigated area in the country (Loiola \& Souza, 2001), increasing to $2.4 \%$ in 2006 and to $5.4 \%$ in 2017.

The Midwest increased its irrigated area by 280,047 ha (48.3\%) in the 2006-2017 period (Figure 2A), standing out for concentrating $48.4 \%$ of areas with high suitability for irrigation and $33.4 \%$ of the areas with high-medium suitability (Sparovek et al., 2015).

With 131,145 recorded establishments using irrigation, the irrigation method covering the largest area in Brazil is sprinkler irrigation, which totaled 3.31 Mha in 2017, a 33.3\% increase compared to 2006 (Figure 2B). In this period, the area irrigated only by center pivot increased by $60.7 \%$, reaching 1.44 Mha. Next, the localized methods stood out with 1.68 Mha in 2017, a $409 \%$ increase compared to the previous survey (330,800 ha), and with 249,772 establishments recorded in 2017. Surface irrigation methods have the third largest irrigated area in the country (1.54 Mha), with a $13.7 \%$ increase compared to 2006 $(36,080$ establishments). Despite this, the area under furrow irrigation decreased by $52.7 \%$ (Figure $2 \mathrm{~B}$ ), mainly due to its limitations when compared to other methods. Irrigation in areas with table tomato has been carried out using this method but, according to Testezlaf (2017), as it is not the most efficient method and because of the lack of information of farmers, its use tends to decrease in the next years.

According to the scenario of expansion in the irrigated area with projection for 2030 carried out by the National Water Agency (ANA, 2017), non-mechanized systems such as furrow and flood irrigation are expected to undergo a retraction, being either replaced by others or discontinued in some areas, with the exception of flooded rice, which has a trend of stabilization in the main centers of the country, mainly in Rio Grande do Sul, with an irrigated area of $1,113,500$ ha in the $2013 / 2014$ season (Köpp et al., 2016). Also, according to these projections, the net estimated growth of irrigation methods will be concentrated in drip irrigation and micro-sprinkler irrigation.

The area with localized irrigation showed higher values than those of center pivot in 2017 (Figure 2B), due to its demand in the Southeast region, mainly in coffee crops (Assis et al., 2014), which grew by $37 \%$ in the number of trees planted between 2006 and 2017, and citrus (Palaretti et al., 2011; Santos et al., 2016) (Figure 3B). In addition, the lower demand for water and inputs caused localized irrigation to expand to areas previously occupied by other irrigation systems (ABIMAQ, 2018).

In the Northeast region, the area under surface irrigation decreased by $64.5 \%$ from 2006 (Figure 3A) to 2017 (Figure 3B)
A.

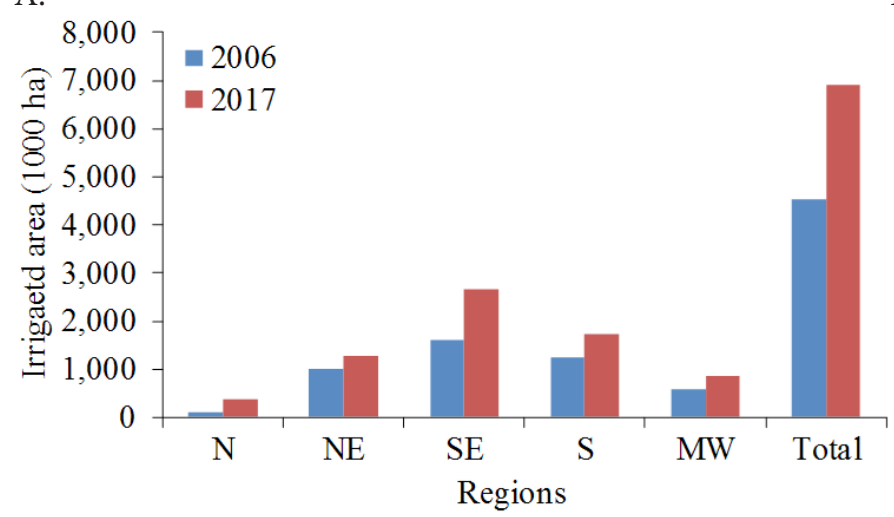

B.

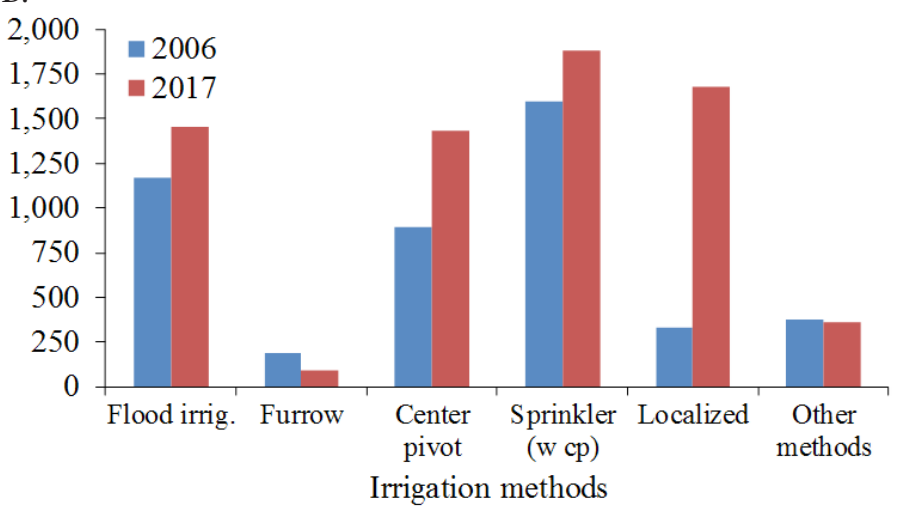

Figure 2. Comparison of irrigated area by administrative region (A) and irrigation system/method (B) in 2006 and 2017
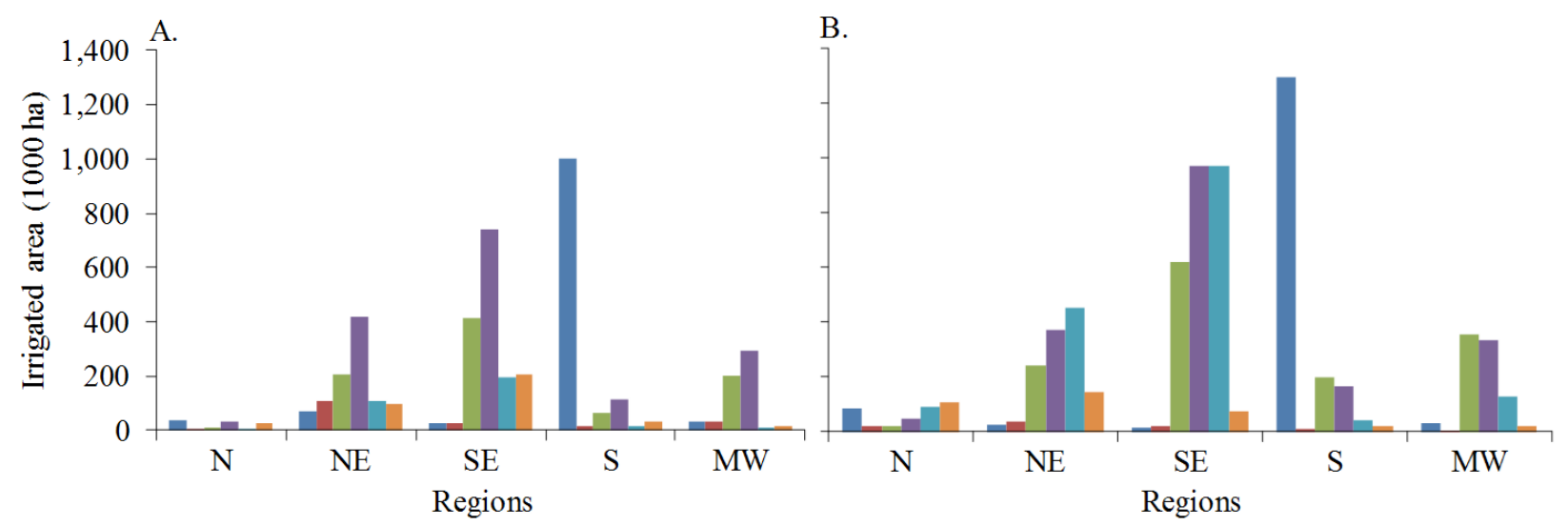

$\square$ Flood $\square$ Furrow $\square$ Center pivot $\square$ Sprinkler (without pivot) $\square$ Localized $\square$ Others methods

Figure 3. Irrigated area by system/method and by region of Brazil, in 2006 (A) and 2017 (B) 
and one of the reasons for such reduction is the conversion to the localized method (drip and micro-sprinkler), which increased by $328.1 \%$, mainly in the irrigated perimeters, such as Mandacaru in Juazeiro, BA, Brazil, state with the largest irrigated area in the Northeast region. According to CODEVASF (2018), the furrow irrigation system has been used in this region for many years, but since 2010 it has been replaced with drip and micro-sprinkler systems, resulting in saving of $50 \%$ of the total water used in perimeter irrigation.

Also with regard to localized irrigation, there was also a significant increase in the North $(1,731.3 \%)$, Southeast $(402.7 \%)$ and Midwest $(1,234.9 \%)$ regions (Figure 3). Additionally, there was an increase of areas under sprinkler irrigation (without pivot) in the South (49.1\%) and Southeast (31.1\%) regions and under center pivot irrigation in the South (220.5\%) and Midwest (76.7\%) regions.

The drip irrigation system has the largest area in establishments of up to 50 ha $(617,423$ ha) (Table 1), followed by conventional sprinkler (514,893 ha) (Table 2 ), mainly in the Southeast region. The establishments with these systems totalize 119,233 and 95,587 , respectively, in which 39,119 and 38,849 are located in the Southeast region. Drip irrigation stands out in the Northeast region $(157,353$ ha, in 55,860 establishments) and micro-sprinkler is more widely used in the Southeast (239,380 ha) and Northeast (148,247 ha). Flood irrigation has a larger irrigated area in the South of the country and furrow irrigation has a larger area in the Northeast region. In general, the localized irrigation method is the most present in areas up to 50 ha.
For establishments larger than 50 ha, the center pivot is the one with the largest irrigated area $(1,362,828 \mathrm{ha}$ ) (Table 2$)$, followed by flood irrigation $(1,282,084 \mathrm{ha})$ and self-propelled sprinkler $(748,504 \mathrm{ha})$. In addition to the methods mentioned, conventional sprinkler irrigation and drip irrigation also stand out in establishments with areas larger than 50 ha, mainly in the Southeast and Northeast regions, respectively, totaling 7,012 and 7,472 establishments (conventional sprinkler irrigation) and 6,259 and 10,323 establishments (drip irrigation).

The other irrigation methods (subsurface, wetting and others) are used in more than 360,000 ha, and prevail in establishments up to 5 ha $(78,863$ ha) (Table 2).

Producers without crop area (WCA) are present throughout the national territory and irrigate approximately 300,000 ha in 3,238 establishments, especially the conventional sprinkler method (63,299 ha) in the Southeast region (Table 2), and other methods in the North region $(42,466$ ha). It is worth pointing out that the producers without crop area are those who produced on leased land, but who were no longer using the land on the reference date of the survey (30/09/2017).

The states of Rio Grande do Sul, Minas Gerais and São Paulo are the ones with the largest irrigated area in Brazil according to the 2017 Census (Figure 4). Rio Grande do Sul is the largest producer of irrigated rice, representing about $78 \%$ of the country's total production. However, in recent years, there has been a relative stability of the area cultivated with rice, with a trend of slight increase in the medium term (ANA, 2017). However, other crops such as corn, wheat and soybean have been gaining prominence in the Northwest Region of Rio

Table 1. Irrigated area (ha) by region and by groups of crop area of the agricultural establishments for irrigation systems drip irrigation, micro-sprinkler irrigation and other localized systems, flood irrigation and furrow irrigation, in 2017

\begin{tabular}{|c|c|c|c|c|c|c|c|c|}
\hline \multirow{2}{*}{ Region/Brazil } & \multicolumn{6}{|c|}{ Crop area of the agricultural establishments (ha) } & \multirow{2}{*}{ WCA } & \multirow{2}{*}{ Total } \\
\hline & $0-5$ & $5-10$ & $10-50$ & $50-100$ & $100-500$ & $>500$ & & \\
\hline \multicolumn{9}{|c|}{ Drip } \\
\hline North & 7,923 & 4,782 & 6,359 & 3,457 & 3,542 & 6,399 & 2,073 & 34,535 \\
\hline Northeast & 86,225 & 25,664 & 45,464 & 14,265 & 33,024 & 34,630 & 6,453 & 245,725 \\
\hline Southeast & 99,615 & 66,579 & 238,653 & 40,351 & 94,185 & 120,825 & 14,009 & 674,217 \\
\hline South & 8,059 & 4,903 & 9,695 & 1,769 & 3,241 & 1,586 & 1,074 & 30,327 \\
\hline MidWest & 6,233 & 2,678 & 4,591 & 1,858 & 5,477 & 22,987 & 10,091 & 53,915 \\
\hline Brazil & 208,055 & 104,606 & 304,762 & 61,700 & 139,469 & 186,427 & 33,700 & $1,038,719$ \\
\hline \multicolumn{9}{|c|}{ Micro-sprinkler and others } \\
\hline North & 7,425 & 4,167 & 35,202 & 1,093 & 2,367 & 4,239 & 2,865 & 57,358 \\
\hline Northeast & 64,203 & 44,787 & 39,257 & 12,579 & 23,620 & 12,217 & 9,067 & 205,730 \\
\hline Southeast & 107,907 & 54,627 & 76,846 & 18,164 & 25,684 & 9,485 & 4,425 & 297,138 \\
\hline South & 2,629 & 1,776 & 3,041 & 422 & 703 & 693 & 344 & 9,608 \\
\hline MidWest & 2,320 & 1,000 & 2,315 & 924 & 60,516 & 338 & 4,556 & 71,969 \\
\hline Brazil & 184,484 & 106,357 & 156,661 & 33,182 & 112,890 & 26,972 & 21,257 & 641,803 \\
\hline \multicolumn{9}{|c|}{ Flood irrigation } \\
\hline North & 335 & 45 & 386 & 1,279 & 13,554 & 65,882 & 5,985 & 87,466 \\
\hline Northeast & 9,888 & 2,939 & 4,015 & 809 & 929 & X & 3,328 & 25,910 \\
\hline Southeast & 2,882 & 1,165 & 1,694 & 1,721 & 2,305 & $X$ & 1,078 & 13,455 \\
\hline South & 3,745 & 10,368 & 102,503 & 90,882 & 416,726 & 655,833 & 15,488 & $1,295,545$ \\
\hline MidWest & 148 & 256 & 289 & 541 & 4,315 & 20,696 & 2,945 & 29,190 \\
\hline Brazil & 16,998 & 14,773 & 108,887 & 95,232 & 437,829 & 749,023 & 28,824 & $1,451,566$ \\
\hline \multicolumn{9}{|c|}{ Furrows } \\
\hline North & 1,376 & 129 & 206 & X & 159 & 15,461 & $X$ & 19,246 \\
\hline Northeast & 15,857 & 3,716 & 3,132 & 665 & 295 & $X$ & 1,494 & 37,739 \\
\hline Southeast & 438 & 300 & 439 & 260 & $X$ & 12,198 & 4,651 & 20,193 \\
\hline South & 98 & 92 & 439 & 532 & 4,021 & $X$ & $X$ & 11,351 \\
\hline MidWest & 359 & 146 & 295 & X & $X$ & $X$ & $X$ & 1,211 \\
\hline Brazil & 18,128 & 4,383 & 4,511 & 1,600 & 7,256 & 44,555 & 9,307 & 89,740 \\
\hline
\end{tabular}

WCA - Producer without crop area; X - Not informed 
Table 2. Irrigated area (ha) by region and by groups of crop area of the agricultural establishments for the irrigation systems self-propelled sprinkler, center pivot sprinkler, conventional sprinkler and other methods, in 2017

\begin{tabular}{|c|c|c|c|c|c|c|c|c|}
\hline \multirow{2}{*}{ Region/Brazil } & \multicolumn{6}{|c|}{ Crop area of the agricultural establishments (ha) } & \multirow{2}{*}{ WCA } & \multirow{2}{*}{ Total } \\
\hline & $0-5$ & $5-10$ & $10-50$ & $50-100$ & $100-500$ & $>500$ & & \\
\hline \multicolumn{9}{|c|}{ Self-propelled sprinkler } \\
\hline North & 458 & 171 & 373 & X & $x$ & 16,909 & 1,455 & 19,851 \\
\hline Northeast & 750 & 510 & 795 & 796 & 3,977 & 74,798 & 1,364 & 82,990 \\
\hline Southeast & 1,789 & 1,504 & 7,911 & 4,956 & 24,838 & 290,004 & 2,503 & 333,505 \\
\hline South & 866 & 1,183 & 4,133 & 1,890 & 6,200 & 79,468 & 1,665 & 95,405 \\
\hline MidWest & 404 & 253 & 864 & $X$ & $x$ & 238,629 & 2,913 & 248,617 \\
\hline Brazil & 4,267 & 3,621 & 14,076 & 8,715 & 39,981 & 699,808 & 9,900 & 780,368 \\
\hline \multicolumn{9}{|c|}{ Center pivot sprinkler } \\
\hline North & 533 & 380 & 549 & X & 1,817 & 16,475 & 1,412 & 21,640 \\
\hline Northeast & 1,573 & 941 & 13,291 & $x$ & 12,075 & 202,809 & 4,171 & 243,223 \\
\hline Southeast & 2,438 & 1,860 & 16,767 & 23,350 & 178,700 & 387,202 & 7,683 & 618,000 \\
\hline South & 1,293 & 879 & 2,123 & 3,204 & 41,347 & 142,502 & 5,730 & 197,078 \\
\hline MidWest & 633 & 275 & 3,218 & 5,547 & 63,258 & 275,705 & 6,460 & 355,096 \\
\hline Brazil & 6,470 & 4,335 & 35,948 & 40,938 & 297,197 & $1,024,693$ & 25,456 & $1,435,037$ \\
\hline \multicolumn{9}{|c|}{ Conventional sprinkler } \\
\hline North & 5,133 & 2,776 & 3,865 & 1,282 & 2,915 & 5,645 & 3,764 & 25,380 \\
\hline Northeast & 42,932 & 31,241 & 24,415 & 8,378 & 23,522 & 138,060 & 17,041 & 285,589 \\
\hline Southeast & 209,353 & 31,630 & 70,489 & 14,259 & 21,389 & 224,557 & 63,299 & 634,976 \\
\hline South & 13,029 & 13,609 & 19,302 & 3,957 & 8,744 & 6,233 & 4,479 & 69,353 \\
\hline MidWest & 40,274 & 2,693 & 4,152 & 1,205 & 4,203 & 22,854 & 7,704 & 83,085 \\
\hline Brazil & 310,721 & 81,949 & 122,223 & 29,081 & 60,773 & 397,349 & 96,287 & $1,098,383$ \\
\hline \multicolumn{9}{|c|}{ Subsurface + wetting + others methods } \\
\hline North & 13,171 & 4,125 & 9,580 & 1,764 & $x$ & 1,507 & 42,466 & 106,709 \\
\hline Northeast & 35,082 & 56,677 & 36,353 & 3,634 & 1,668 & $x$ & 5,463 & 141,702 \\
\hline Southeast & 21,895 & 5,831 & 8,736 & 1,801 & $X$ & 11,260 & 17,069 & 73,964 \\
\hline South & 4,628 & 1,596 & 3,814 & 929 & 2,477 & $X$ & 613 & 22,645 \\
\hline MidWest & 4,093 & 789 & 1,022 & 626 & $X$ & 286 & 8,048 & 18,764 \\
\hline Brazil & 78,863 & 69,018 & 59,503 & 9,251 & 44,951 & 26,749 & 75,449 & 363,784 \\
\hline
\end{tabular}

WCA - Producer without crop area; X - Not informed

Grande do Sul (Manke et al., 2017), forming one of the main centers of recent expansion of center pivot irrigation (ANA, 2017), thus justifying the increase in irrigated area in the State compared to the 2006 Census (Figure 4).

Minas Gerais was the State with highest growth rate of irrigated area in the 2006-2017 period (116.1\%), changing from 530,042 to $1,145,628$ ha, and surpassing the State of São Paulo, which irrigated 786,051 ha until 2006 (Figure 4). The state has gained notoriety mainly due to the expansion of the area irrigated with center pivot (ANA, 2017), which already has about $29 \%$ of the total area of the country irrigated by this system. This expansion of the center pivot stands out in the Triângulo Mineiro region, with 134,700 ha irrigated (Ferreira et al., 2018) and in the municipalities of Unaí and

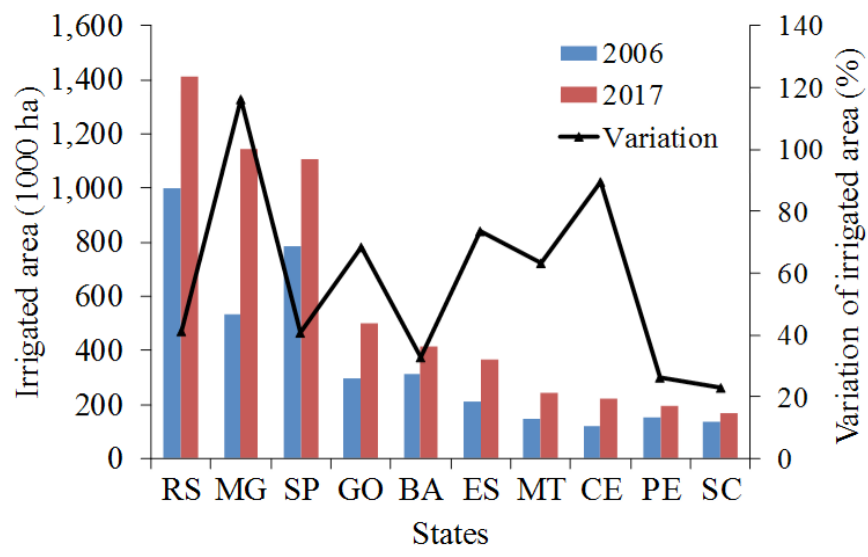

Figure 4. Variation of the irrigated area from 2006 to 2017 in the 10 main irrigating States in Brazil
Paracatu (Ferreira et al., 2011), located in the Northwest region of the State, mainly for the cultivation of cereals (soybean, corn and beans) and sugarcane, especially in the municipality of Paracatu (ANA, 2017). The Northern region of the State also has important irrigated areas, mainly in the projects Gorutuba (Reis et al., 2012) and Jaíba (Duarte \& Tavares, 2001). Besides Minas Gerais, the sprinkler irrigation system with center pivot is the reason for the increment in the irrigated areas of the States of São Paulo (40.8\%), Goiás (68.5\%) and Bahia (32.8\%).

The State of Ceará had the second highest growth rate of irrigated area in the period ( $89.5 \%$ ), changing from 117,381 to 222,478 ha and surpassing the states of Pernambuco and Santa Catarina, which irrigated 152,917 and 136,249 ha in 2006 and 192,806 and 167,473 ha in 2017 , respectively. This expansion is mainly due to the significant participation in fruit agribusiness, which during the 2010 - 2013 period enabled an expansion in the volume of production and commercialization of irrigated fruit crops, in response to the development of technologies applied in the abstraction, damming and channeling of water reservoirs (Ferreira et al., 2016). According to Rigotto et al. (2016), the organization of the State in agricultural centers made it possible to identify regions with greater potential for irrigation, enabling the creation of a master plan, aiming at improvements in the organization of irrigated perimeters cultivated with fruits and flowers and in financing lines such as those of the Growth Acceleration Project. In addition, the States of Ceará and Rio Grande do Norte have the most important irrigated perimeters of the Northeast region (Vidal 
\& Ximenes, 2016), especially Baixo Acaraú and Santa Cruz do Apodi, respectively.

Espírito Santo also showed a significant growth rate of irrigated area $(73.7 \%)$. Due to the reduction in water availability in recent years, there has been a change in irrigation methods and the localized system has become the most used $(302,533 \mathrm{ha})$ (Dadalto et al., 2016). The State is a reference in coffee cultivation, with about $80 \%$ of the national production of Conilon coffee, predominantly grown under irrigation (Bonomo et al., 2013).

Favored by the support from public banks, as executors of credit and agricultural insurance policies, the State of Mato Grosso had the fourth highest growth rate of irrigated area in the period from 2006 to 2017 (63.2\%). This State is one of the centers of agriculture irrigated by center pivot, with $6 \%$ of the area of the country (ANA, 2017), irrigating mainly plantations of common bean, corn, soybean and cotton. These numbers tend to grow in the next years, since the State has $15.5 \%$ of the additional irrigable area in Brazil (9.5 Mha), with 4.63 Mha located in areas with high suitability of soil and relief (Sparovek et al, 2015).

\section{Conclusions}

1. The total irrigated area in Brazil was $6,902,960$ ha in 2017, increasing by $51.9 \%$ compared to the 2006 survey.

2 . The most representative irrigation systems in the country are: sprinkler (without center pivot) (27.2\%), localized irrigation $(24.4 \%)$, flood irrigation $(21 \%)$ and center pivot (20.8\%).

3. The Southeast is the main irrigating region in the country, followed by the South, Northeast, Midwest and North regions, with the largest irrigated area in the States of Rio Grande do Sul, Minas Gerais and São Paulo, representing, respectively, $20.4,16.6$ and $16.0 \%$ of the country's total irrigated area.

4. The State of Minas Gerais showed the largest increase in irrigated area, followed by Rio Grande do Sul and São Paulo, mainly due to the expansion of areas irrigated with center pivot, especially under cereal production.

\section{Literature Cited}

ABIMAQ - Associação Brasileira da Indústria de Máquinas e Equipamentos. Available on: <http://abimaq.org.br/site.aspx/ Imprensa-Clipping-Tendencias-setalhe?Detalhe Clipping=1796 >. Acessed on: dezembro de 2018.

ANA - Agência Nacional de Águas. Atlas irrigação: Uso da água na agricultura irrigada. Brasília, ANA, 2017. 86p.

Assis, G. A. de; Scalco, M. S.; Guimarães, R. J.; Colombo, A.; Dominghetti, A. W.; Matos, N. M. S. de. Drip irrigation in coffee crop under different planting densities: Growth and yield in Southeastern Brazil. Revista Brasileira de Engenharia Agrícola e Ambiental, v.18, p.1116-1123, 2014. https://doi.org/10.1590/18071929/agriambi.v18n11p1116-1123

Bonomo, D. Z.; Bonomo, R.; Partelli, F. L.; Souza, J. M. de; Magiero, M. Desenvolvimento vegetativo do cafeeiro conilon submetido a diferentes lâminas de irrigação. Revista Brasileira de Agricultura Irrigada, v.7, p.157-169, 2013. https://doi.org/10.7127/rbai. v7n200008
CODEVASF - Companhia de Desenvolvimento dos Vales do São Francisco e do Parnaíba. Mandacaru. 2018 Available on: < https:// www.codevasf.gov.br/principal/perimetros-irrigados/elenco-deprojetos/mandacaru $>$. Acessed on: dezembro de 2018.

Dadalto, G. G.; Silva, A. E. S. da; Costa, E. B. da; Galvêas, P. A. O.; Loss, W. R. Transformações da agricultura capixaba: 50 anos. 1.ed. Vitória: Cedagro; Incaper; Seag. 2016. 128p.

Darko, R. O.; Yuan, S.; Hong, L.; Liu, J.; Yan, H. Irrigation, a productive tool for food security - a review. Acta Agriculturae Scandinavica, Section B - Soil \& Plant Science, v.66, p.191-206, 2015. https:// doi.org/10.1080/09064710.2015.1093654

Ding, G. K. C.; Ghosh, S. Sustainable water management - A strategy for maintaining future water resources. Encyclopedia of Sustainable Technologies, p.91-103, 2017. https://doi.org/10.1016/ B978-0-12-409548-9.10171-X

Duarte, S. V.; Tavares, M. C. Sistema de distribuição de produtos agrícolas: facilidades e dificuldades do escoamento da produção - Um estudo de caso do projeto Jaíba. Unimontes Científica. v.2, p.1-25, 2001.

FAO - Food and Agriculture Organization. Agricultura irrigada sustentável no Brasil: Identificação de áreas prioritárias. Brasília, 2017. 243p.

Ferreira, D. S.; Ribeiro, W. R.; Gonçalves, M. S.; Pinheiro, A. A.; Sales, R. A. de; Reis, E. F. Cenário da área irrigada por pivô central no Triangulo Mineiro, no Estado de Minas Gerais, Brasil. Nativa, v.6, p.613-618, 2018. https://doi.org/10.31413/nativa.v6i6.5864

Ferreira, E.; Toledo, J. H. de; Dantas, A. A. A.; Pereira, R. M. Cadastral maps or irrigated areas by center pivots in the state of Minas Gerais, using CBERS-2B/CCD satellite imaging. Engenharia Agrícola, v.31, p.771-780, 2011.https://doi.org/10.1590/S0100-69162011000400015

Ferreira, M. J. M.; Viana Júnior, M. M.; Pontes, A. G. V.; Rigotto, R. M.; Gadelha, D. Gestão e uso dos recursos hídricos e a expansão do agronegócio: Água para quê e para quem? Ciência \& Saúde Coletiva, v.21, p.743-752, 2016. https://doi.org/10.1590/141381232015213.21012015

IBGE - Instituto Brasileiro de Geografia e Estatística. Manual do Recenseador CA - 1.09: Censo Agro 2017. Rio de Janeiro: IBGE. 2017. 147p.

Köpp, L. M.; Peiter, M. X.; Robaina, A. D.; Toescher, C. F. Caracterização de estações de bombeamento em lavouras de arroz do Rio Grande do Sul. Engenharia Agrícola, v.36, p.342-351, 2016. https:/doi. org/10.1590/1809-4430-Eng.Agric.v36n2p342-351/2016

Loiola, M. L.; Souza, F. D. de. Estatísticas sobre irrigação no Brasil segundo o Censo Agropecuário 1995-1996. Revista Brasileira de Engenharia Agrícola e Ambiental, v.5, p.171-180, 2001. https:// doi.org/10.1590/S1415-43662001000100033

Manke, E. B.; Faria, L. C.; Pereira, M. G.; Norenberg, B. G.; Caldeira, T. L.; De Oliveira, H. F. E. de. Identificação de áreas irrigadas por pivô central e linear móvel no estado do Rio Grande do Sul. Irriga, v.22, p.343-352, 2017. https://doi.org/10.15809/ irriga.2017v22n2p343-352

Palaretti, L. F.; Mantovani, E. C.; Sediyama, G. C. Caracterização e diagnóstico de sistemas de irrigação e práticas de manejo de água na citricultura do norte do estado de São Paulo. Cadernos de Ciência \& Tecnologia, v.28, p.531-551, 2011.

Paulino, J.; Folegatti, M. V.; Zolin, C. A.; Sánchez-Román, R. M.; José, J. V. Situação da agricultura irrigada no Brasil de acordo com o censo agropecuário 2006. Irriga, v.16, p.163-176, 2011. https:// doi.org/10.15809/irriga.2011v16n2p163 
Reis, P. R. da C.; Silveira, S. F. R.; Rodrigues, P. E. L. Impactos da Política Nacional de Irrigação sobre o desenvolvimento socioeconômico da região Norte de Minas Gerais: Uma avaliação do Projeto Gorutuba. Revista Administração Pública, v.46, p.1101130, 2012. https://doi.org/10.1590/S0034-76122012000400010

Rigotto, R. M.; Freitas, B. M. C.; Maia, R. C. C.; Gadelha, D.; Veríssimo, A. G. P.; Teixeira, M. M.; Costa, D. S. Perímetros irrigados e direitos violados no Ceará e Rio Grande. Revista Pegada, v.17, p.122-144, 2016. https://doi.org/10.33026/peg.v17i2.4684

Saccon, P. Water for agriculture, irrigation management. Applied Soil Ecology, v.123, p.793-796, 2018. https://doi.org/10.1016/j. apsoil.2017.10.037

Santos, M. R.; Donato, S. L. R.; Coelho, E. F.; Arantes, A. de M.; Coelho Filho, M. A. Irrigação lateralmente alternada em lima ácida 'Tahiti' na região norte de Minas Gerais. Irriga, v.1, p.71-88, 2016. https:// doi.org/10.15809/irriga.2016v1n01p71-88
Sparovek, G.; Leite, C. V.; Barreto, A. G. O. P.; Maule, R. F.; Dourado Neto, D. Análise territorial e potencial da agricultura irrigada no Brasil. ITEM - Irrigação \& Tecnologia Moderna, v.106, p.50-55, 2015.

Testezlaf, R. Irrigação: Métodos, sistemas e aplicações. Unicamp/ FEAGRI, 2017. 215p.

Velasco-Muñoz, J. F.; Aznar-Sánchez, J. A.; Belmonte-Ureña, L. J.; Román-Sánchez, I. M. Sustainable water use in agriculture: A review of worldwide research. Sustainability, v.10, p.1-18, 2018. https://doi.org/10.3390/su10041084

Vidal, M. F.; Ximenes, L. J. F. Comportamento recente da fruticultura nordestina: Área, valor da produção e comercialização. Caderno Setorial ETENE, v.1, p.18-26, 2016.

Winter, J. M.; Lopez, J. R.; Ruane, A. C.; Young, C. A.; Scanlon, B. R.; Rosenzweig, C. Representing water scarcity in future agricultural assessments. Anthropocene, v.18, p.15-26, 2017. https://doi. org/10.1016/j.ancene.2017.05.002 